\title{
Public Access: For Socially Relevant Knowledge Production and a Democratic Cybersphere
}

\author{
Joshua Sbicca, Robert Todd Perdue
}

\section{Introduction}

In the "Information Age", power is largely a function of accessibility to, and control over, information and communication (Castells 2000, 2009). The development of the Internet and associated technologies is the primary driver of this shift, forever changing how information is produced, consumed, and dispersed. At the same time, we commonly hear that "knowledge is power", and that the Internet has the potential to democratize the knowledge production process, opening up the intellectual sphere to non-academic publics (Agger 2004; Agger 2006). Given the centrality of science in producing knowledge, we set out to analyze the economic, social, and political conditions which create and inhibit open dissemination and production of this information. In many ways, academics in the Information Age have greater opportunities to share their findings with those outside of the university than at any other time in history. Open Access (OA) is one way to share research with less well funded institutions and engage civil society and policy makers. Therefore a deeper explication of this new, more decentralized and democratic knowledge dissemination project is needed (Shiltz et al. 2005).

The Berlin Declaration on Open Access to Knowledge in the Sciences and Humanities conceived of OA as:

a comprehensive source of human knowledge and cultural heritage that has been approved by the scientific community. In order to realize the vision of a global and accessible representation of knowledge, the future Web has to be sustainable, interactive, and transparent. Content and software tools must be openly accessible and compatible. Our mission of disseminating knowledge is only half complete if the information is not made widely and readily available to society (2003).

As such, $\mathrm{OA}$ advocates argue the importance of producing high quality research and making this information widely available without cost. Many questions remain, however, as to whether having access to more scholarly research through new technological mediums will lead to a more informed and reflexive public, especially given that the peer review process may reproduce knowledge considered relevant to scholars, but not to the public (Valsiner 2006). Moreover, such advocates often proclaim the merits of OA without considering how the reward systems of academic institutions (e.g. greater access equals more citations) might obstruct more liberatory models of knowledge production and dissemination.

This article contributes to the small but growing debate about the merits, role, and potential of OA scientific research. We provide a sociological critique[1] of OA by investigating the assumptions of OA advocates. As a corollary, we present some of the debates among scholars attentive to OA as well as similar digital and internet based technologies.[2] Such an investigation allows us to position the discipline of sociology within debates over the changing digital landscape, namely how Internet technologies make accessing scientific knowledge possible.[3]

Furthermore, an investigation of OA lays a foundation for probing the appropriate role of the sociologist, and maybe more broadly the scholar in the Information Age by tying debates regarding the potential for a democratic cybersphere and public sociology. Central to public sociology is a commitment to addressing extra-academic 
audiences through reflexive knowledge production that interrogates social and professional values (Burawoy 2005). Within this debate, some scholars contend that sociology is the discipline with a mandate to foster liberatory social change (Feagin and Vera 2008) and should be overtly political (Piven 2007), while others contend that sociology must be a value-free science in order to maintain legitimacy (Stinchcombe 2007). Most forcefully, Agger (2000) argues that the primacy of positivism and quantitative methods and the de-emphasis on narrative has resulted in a hollow, stagnant discipline disengaged with the public sphere. After exploring contrary views on the appropriate relationship between academia and society, we point out that few of these discussions focus on accessibility and the changing knowledge landscape in society 2.0. We attempt to push the discussion in this direction by pointing out the many constraints faced by academics in the current education atmosphere, especially the publication and funding obligations of tenure obtainment.

We outline some critical approaches to knowledge production to provide a foundation for our notion of public access (PA), a form of praxis that includes OA, but goes further, prioritizing reflexivity and the co-creation of knowledge with publics, especially historically marginalized groups. [4] We contend that those outside of academia have much to offer researchers by providing important information and perspective that may otherwise be missed, leading to more informed understandings of social reality. Influenced by the pragmatist tradition, we recognize that knowledge is fluid and provisional. Moreover, participation and pluralism are the keys to any useful science, as we contend that developing strategies for emancipatory social change must be grounded in social "reality", which can best be obtained by collectively plumbing with publics the vast well of social information.

In this way we argue that $\mathrm{OA}$ is a necessary but insufficient condition for a sociology that seeks transformative social change. Whether this is within the purview of sociology or any other discipline, however, is still an open question, and in need of sustained discussion. Nevertheless, the accessibility of scholarly research is an understudied subject and necessitates a critical reevaluation of what this looks like within the context of advancing a democratic cybersphere.

\section{| From Knowledge "For" Publics to Knowledge "With” Publics}

To help produce socially relevant knowledge requires scientific autonomy and new institutional avenues of knowledge dissemination. For Bourdieu (1996), social scientists should form an international association to develop and disseminate knowledge without the mediating influence of economics or the state. This association would allow intellectuals to collectively intercede in important political affairs while maintaining individual expertise (Bourdieu and Wacquant, 1993). However, autonomous modes of knowledge dissemination do not account for scholar's relationship to multiple publics. Thus, Burawoy (2005) contends that public sociology - which actively engages civil society, is reflexive, and seeks to create positive social change - ought to be valued as highly as "professional" or supposedly value-neutral sociology. Along with public and professional sociology, he further divides the labor within the field into critical sociology, which challenges the sociological orthodoxy, and policy sociology which works with interests outside of academia (but risks co-optation by political and economic elites). The key point is that the typology is not a hierarchy, as Burawoy argues that all four areas of sociology are valuable and necessary for a vibrant discipline, but public sociology and its scholar-activists need to be esteemed for their engagement with the world outside of the ivory tower.

Burawoy's (2005) typology and notion of public sociology stimulated much debate and revealed the Balkanization of the discipline. In 2007, at Burawoy's urging, many of these critiques were compiled into Public Sociology: Ideas, Arguments and Visions for the Future. Reflecting the European view of sociology, Touraine (2007) contends that public engagement is central to sociology. Creating his own typology, Wallerstein (2007) largely agrees with Burawoy, holding that the work of sociologists should fulfill analytical, moral and political functions. Collins (2007) worries that labeling this work as 'public sociology' will only further "ghettoize" the discipline and marginalize those already practicing public sociology. Embracing a more radical stance, Piven (2007) contends that sociology should be overtly leftist and work primarily with publics at the bottom of social hierarchies. Massey (2007) on the other hand, strongly disagrees, arguing that sociology already holds scant credibility among political elites and further politicization will leave it voiceless. Smith-Lovin (2007) and Stinchcombe (2007) assert that public sociology will only undermine the true goal of the discipline, knowledge production through rigorous engagement with appropriate theory and methods. Stinchcombe (2007) goes as far as to say that academics should be isolated in the ivory tower in order to 
generate "truth" untainted by political motives.

For his part, Burawoy (2008) argues for moving beyond the sociological imagination, which he sees as elitist and insufficient, and argues for a political imagination. Such an imagination allows social scientists to work from a particular standpoint in solidarity with historically marginalized groups, instead of independently doing research for and speaking at publics. Moreover, a political imagination will allow social scientists to create a more "humane, equal and just society" (Burawoy 2008: 374), or what Wright (2010) calls "real utopias". The political imagination does not, however, address how learning and teaching are dialectical, nor does it outline a path towards the production of socially relevant knowledge.

A more emancipatory vision is found in the work of those influenced by Marx and the Frankfurt School. For example, Marx (1998) originally contented that the goal of science is not simply to understand the world, but to change it. The Frankfurt School continued this critical tradition by investigating the role that various ideologies play in dominating publics, essentially providing a contemporary framework for understanding how the formation and dissemination of ideas mutually constitutes economic exploitation (Horkheimer and Adorno 2002; Marcuse 1964). Such domination and exploitation are not total; there is always room for resistance and transformation (Marcuse 1964).

In a work that critically recognizes the power of dominating ideologies and their exploitative material scaffolding, but maintains that social emancipation is possible, The Pedagogy of the Oppressed argues for education aimed at creating a more humane society (Freire 1992). This seminal work asserts that the dialectic between oppressors (those benefiting from structures maintaining privilege and power in a historically specific moment) and oppressed (those historically exploited on the basis of race, class, nationality, gender and/or sexuality, and at a distinct structural disadvantage) can be transformed through praxis. Praxis is "reflection and acting upon the world in order to transform it" (Freire 1992: 36). Moreover, the humanization of society can only arise when those with power trust those who have been historically marginalized by working alongside them in a broader struggle for social change (Freire 1992: 47). While it is laudable for social scientists to carry out research with a socially just aim, if there is no mutually trustworthy relationship with the community or group who benefits from such an aim, oppressive relations will continue.

This trust is especially important in light of processes supporting the internalization of oppressors' views (Fanon 1967). Such relations have profoundly negative implications for education. First, historically marginalized groups' knowledge of the world is often viewed as uninformed and naive by the dominant group. Moreover, those in scientific and educational positions often make attempts to commensurate history and psychological, economic, and religious values of less powerful groups into a quantifiable figure (Espeland 1998). The ability to define the knowledge of the less powerful in the discourse of the powerful perpetuates inequality. Second, maintaining the political, economic, and social status quo in the United States (US) depends on the political indoctrination of children in American classrooms.

Education largely rests on the premise that those in front of the classroom hold all the knowledge and those in the seats are sponges for such knowledge. If the relationship between knower and learner stays as is, dehumanizing relations will remain in perpetuum. One can characterize the knowledge production approach as a banking model of education, which aims to produce a particular outcome. Teacher presents material. Material is memorized. Material is repeated back to the teacher in some evaluation format. On the other hand, Freire (1992) notes, "I cannot think for others or without others, nor can others think for me. Even if people's thinking is superstitious or naïve, it is only as they rethink their assumptions in action that they can change" (100). This co-intentional educational model promotes teachers and students engaging in dialogue and critically thinking together in order to produce minds capable of independent, insightful thought. Some of the goals of Freire's liberatory education proposals resonate with $\mathrm{OA}$ advocates, which we discuss below by placing such desires within the context of obstructive social forces.

\section{| Open Access in the Context of Institutional Pressures and the Academic Reward Structure}

As Mills (1959) pointed out, universities are often intricately intertwined with corporate and military interests. Moreover, individuals and groups in society often come to accept the institutional perspectives of the economy and state through the institutions of education and the media (Bourdieu 1989). As such, it is critical to consider how institutional norms help to reproduce differences in what is perceived to be legitimate knowledge because people 
often think and act in line with ideas that seep into mainstream culture without critically evaluating their validity. Such a state of affairs is not limited to the general public; intellectuals also internalize institutional forms of knowledge. Aronowitz (2000) argues that the university has become corporatized to the point where many of these institutions are churning out degrees in the name of "education" and "training" instead of "learning." No matter what scientific paradigm may be internal to the scientific enterprise at this time (Kuhn 2012), structural forces of neoliberal state ideology coupled with the accumulation cycles of capitalism increasingly influence what is researched and how, and the organizational form of the university (Giroux 2002; Slaughter and Rhoades 2004). Furthermore, many universities reflect the corporate and government bureaucracies that increasingly influence college professors to adopt similar values instead of values such as human freedom, democracy, and learning (Giroux and Giroux 2006). These social forces impact what is studied, how research is written, and how text both organizes and reinforces different forms of human relationships (Smith, 1989).

Research grants are even more important for academic success and security than publications, and these funds raise numerous ethical questions. For instance, the University of California, Berkeley's acceptance of a $\$ 500$ million energy research grant from British Petroleum (BP) led many to question how these funds would affect future research paths (Altieri 2010). The financial support provided by the pharmaceutical industry to medical schools is another example where influence is exerted early in a career, leading to relationships that benefit industry from the development of prescription of drugs (Wazana 2000; Lexchin et al. 2003). Moreover, given a constrained economic climate, legislators are slashing higher education budgets, leading to a restructuring of the university through a strategy of "management by crisis" (Emery 2010). Such restructuring places an increased emphasis on entrepreneurial attempts to glean money from public and private sources outside the yearly university budget. Thus, there is pressure to spend more time finding outside funding, which typically comes with various constraints and less institutional support for scholars critical of these institutional forces.

One source of such funding is the US government which is increasingly intertwined with academia. A notable early example of this collusion was "Project Camelot" during the 1960s in which the US Army sought to understand the causes of social rebellion (Horowitz 1967). The implicit goal of the project was to thwart socialist uprisings in Latin America that might challenge US political and economic interests. More recently, the Intelligence Community Centers for Academic Excellence (ICCAE) was developed following the attacks of September 11, 2001 in the belief that links between scientists and intelligence agencies would help protect Americans (Ember 2002). Over the previous four years, twenty-two US universities have received these hubs. Moreover, the goals of the US government and military may seep into scholarly circles through programs such as the Human Terrain System (HTS), which embeds social scientists in Afghanistan in order to glean knowledge of indigenous cultures. Such knowledge is used for a number of purposes, including the generation of propaganda in a counterinsurgency war (Price 2010). These are but a few of the numerous examples of how dominant institutions actively infiltrate the academic sphere and drive scholars down intellectual avenues that may be in conflict with maintaining academic integrity and autonomy. Such pressures take on unique characteristics in an era marked by new digital technologies that may provide avenues for circumvention, resistance, and/or transformation.

\section{Bringing in the Question of Open Access}

Although the modern public library symbolizes significant headway in the democratization of information, they are largely dependent on local funding putting libraries in competition with other local needs for a diminishing pool of resources. Research libraries housed at universities and colleges have also seen changes. Whereas before the $1960 \mathrm{~s}$ most scholarly publishing was controlled by non-profit academic and scholarly societies, which necessarily kept the costs of publishing low, commercial publishers are increasingly dominant (Thomes and Clay 1998), leading to greater knowledge commodification. [5] Furthermore, an increasing number of society journals and specialty journals are published by commercial publishing companies. This cost then gets passed along to consumers of academic scholarship in the form of per article pricing, and potentially to students through increased tuition or fees. It is within this context that $\mathrm{OA}$ seeks to alter academic publishing.

Willinsky (2006) argues that what underlies OA is an access principle: "a commitment to the value and quality of research carries with it a responsibility to extend its circulation of this work as far as possible, and ideally to all who are interested in it and all who might profit by it" (5). Librarians are among the more vocal supporters of OA, arguing that there is both a "pricing crisis" and a "permission crisis" (Suber 2003). Many libraries cannot afford the costs of purchasing scholarly journals, while many licensing and archiving restrictions create roadblocks for permanent 
access to such knowledge. The push for OA provides the potential for scholarly research to reach more people. Specifically, the OA principle is premised on access to original scientific research, raw data, scholarly multimedia, source materials, and graphical and pictorial representations used in research. OA supporters argue that in order to begin disseminating knowledge new copyright models are needed. Specifically, OA advocates want models where the author keeps the copyright, or shared models that would use something like a Creative Commons license, which allows for use and reuse of an author's own work (Hoorn and van der Graaf 2006).

OA takes two forms for the consumer of knowledge: gratis OA and libre OA (Suber, 2008). Gratis OA removes price barriers, while libre $\mathrm{OA}$ removes price barriers and some permission barriers. However, for the publisher of OA research there are "green" and "gold" standards. It has been estimated that around $90 \%$ of academic journals are "green" (non-OA journals that allow authors to self-archive in an OA archive) [6] and 10\% are "gold" (OA journals) (Harnard et al. 2008). In short, there are multiple challenges to the OA project resulting from differences in how the knowledge produced by scholars is disseminated.

In our field of study, sociology, the lack of OA journals is striking.[7] In the fall of 2010 we set out to assess the openness of the fifty highest ranked journals according to their impact factor as evaluated in the Journal Citation Reports published by Thomson Reuters on the ISI Web of Knowledge website. We found that just two of the fifty journals offered their content freely to those without institutional affiliations, providing strong evidence for those critical of university isolation from the public (see Appendix A). Below is a further dissection for why these patterns exist, specifically the publishing obstructions to writing for and with the public.

\section{Scholarly Motivations and Institutional Pressures}

While barriers certainly exist to accessing scholarly journals, simply stating an ethical obligation to disseminate such research belies some of the more self-interested motives that may motivate scholars to support the OA movement, namely fulfilling the necessary curriculum vita requirements. Therefore, some studies explore whether $\mathrm{OA}$ articles have a greater research impact than articles only available in print. Some studies find that OA articles have greater research impact as measured by number of citations (Antelman 2004; Harnard et al. 2008; Swan 2010). The only study to use a randomized controlled trial of $\mathrm{OA}$ publishing across the natural sciences, social sciences, and humanities, however, found that $\mathrm{OA}$ articles are downloaded more often, but not cited any more frequently than subscription articles (Davis 2011). Davis argues that those working at prestigious universities already have access to all the literature they need, so OA instead benefits communities of practice such as educators, medical professionals, and policy makers.[8] The access question raises the issue of scholarly motivation, or what Willinsky (2006) calls the "ego economy". Such a culture thrives off the drive for upward mobility within one's discipline, which, while having individual benefits, leads to a widening gap between science and policy, and a reduced commitment to producing socially relevant knowledge (van Dalen and Henkens 2012). On the other hand, academics whose work is more widely read and cited may find it easier to advance their own careers, obtain tenure, collect speaker fees, and gain the respect of colleagues. For example, instead of confinement to one's epistemic community, one may be able to break into the public arena because media and policy makers access OA scientific research. That being said, for the ego economy to result in material benefits within the halls of the academy it is often more important who cites your article rather than if your work is read. This is because of the growing reliance on various bibliometrics and citation indices, such as the impact factor, and h-index. Some research even shows that social media tools such as Twitter can be used to generate buzz around a peer reviewed publication, thus leading to greater social impact of a scientific article and therefore more academic citations, and that alternative metrics can be developed to measure article impact (altmetrics) (Eysenbach 2011). While some scholars may truly be interested in both pressuring publishers to adopt and work to create $\mathrm{OA}$ outlets for scholarly research, personal gain often trumps egalitarian motives.

Such a dour picture must be seen though in light of scholarly attempts at dialogic engagement through the use of platforms and portals such as Facebook, Twitter, wikis, and blogs. As Fitzpatrick (2012) argues, "All these experiments recognize that the critical element in scholarly engagement is participatory exchange and that the dialogic spaces of the read-write Web can be used to support the process of reading and writing within a community in productive ways" (49). The possibility for such participatory approaches increases if we begin to think of communities in a way that includes the lay public. To get from where we are now to a place where greater coproduction of knowledge is possible, we can begin to look at the merits of altmetrics. At a minimum, our measures of "reach" and "impact" can begin to include forms of digital scholarship that circumvent the traditional publishing process (Anderson and McPherson 2011). What might this mean in the context of publishing pressures? 


\section{Publish or Perish?}

Similar to the commodification of scholarly research by political institutions, academic publishing is a commodity concentrated in the hands of a few corporate publishing companies, such as Springer, Elsevier, and Wiley-Blackwell (Merger Mania 2003). It is estimated that these three publishers account for $42 \%$ of all articles published (Morgan Stanley 2002). While scholars are not directly paid for a published article, salary, tenure, and academic positions are directly linked to the volume of publications produced, with little option but to publish articles in journals owned by large publishing companies (Harley and Acord 2011). Company policy often restricts scholars from freely sharing their research, curtailing academic freedom and more public forms of knowledge dissemination. For example, authors are expected to sign over copyrights before the article is published, disallowing scholars from reusing and distributing their research for free to the public. That being said, efforts such as Science Commons are creating tools such as the Scholar's Copyright Addendum Engine. This can be used to create an attachment to a journal publisher's copyright agreement that allows full access, immediate access, and/or delayed access to your article in order to repost it for non-commercial uses. Scholars may confront these pressures, though, only to find that they are marginalized in their respective field (Agger 2000). The commodification of knowledge challenges those working to produce knowledge that questions those systems, institutions, and organizations that perpetuate inequality (Gattone 2006).

As the hackneyed but succinct phrase, "publish or perish" highlights, academics have but little choice to publish in the journals of the major publishing companies and relinquish control of their intellectual property. To "perish" means a failure to obtain tenure, which often results in a status of academic vagabondage.[9] The value of most published scholarly work in this milieu is judged by the prestige of the academic journals where a scholar's research is published, as well as the sheer amount of articles published. Agger (2000) argues that "[T]he authorial choices sociologists make are examined in light of a literal political economy that stratifies publication outlets, both journals and publishing houses, in ways that have direct impact on scholars' careers" (4). This atmosphere leads many researchers to unnecessarily stretch their findings across numerous articles to increase their publication count. Indeed, much sociological research is driven by mining survey data in order to produce a publication rather than seeking to answer socially impactful questions. In addition, Scheff (1995) contends that work that is truly cutting edge is often dismissed:

There are rare exceptions in which career advancement is produced entirely by the originality or importance of one's publications. Of course talent as a teacher is unrelated, or even negatively related to advancement. But in the typical instance, one's writing is judged by a jury of one's peers who are unable or unwilling to recognize originality and importance, especially if it is expressed in a form that is more complex or difficult than their own work. They are taking valuable time out of their busy lives to serve on the jury, and are not liable to spend undue time with difficult cases (157).

In addition, little value is given to work put forth in alternative, non-peer reviewed journals or other media outlets although these formats are often more accessible for those outside of academia.[10] Social scientists are rarely rewarded within academia for community outreach that may involve writing editorials, giving interviews for media outlets, and providing policy assessments for local governments, although integrating these uses of scholarly research builds stronger connections between skeptical publics and isolated intellectuals. For example, scholarly blogs, whether individual or collectively managed, can provide a medium for greater dialogical engagement. As Wade and Sharp (2012) convincingly show, the blog Sociological Images - with a readership of 20,000 people a day - is an important tool for expanding the sociological imagination and launching social action.[11] Such efforts reveal pedagogical diversity within sociology and social science more broadly, but it is still valuable to point out the shortcomings of how knowledge is produced, used, and disseminated in the hopes that OA and other publically engaged projects may expand beyond the parochial concern with knowledge dissemination. Below we begin to flesh out some guiding principles and examples that could do just that.

\section{| Towards Combining Internet and Place Based Democratic Commons: Public Access}

Central to claims that the public has a right to scientific knowledge is the reality that much of what is produced results from public funding. The argument goes that at a minimum, the public should have access to relevant scholarly knowledge, because it is a public good. Much like public parks, public access television, or public radio, we are collectively paying for a good that should benefit society, where one person or group's access is non-exclusive and 
does not lead to scarcity. In an era where intellectual property and patents seek greater enclosure and appropriation many are beginning to argue for scientific knowledge to be treated as part of a commons like the air we breathe or the water we drink (Hess an Ostrom 2005). We agree with these assessments in so far as they are premised on Hardt and Negri's (2009) understanding of knowledge as a part of a cultural commons that involves "both the product of human labor and the means of future production" (139). In short, the laboring public is already involved in the production of knowledge, yet is alienated from the process and product. Many OA advocates fail to recognize this premise and do not appreciate that the scholarship being accessed by the public may be perpetuating institutional forms of knowledge that reflect institutional goals and norms. Power differences are often ignored between the industries that fund scientific research and the public when touting the benefits of journals publishing OA articles. The public is still relying on knowledge that may not be helpful in solving ecological, economic, political or social problems if it overlooks the structural factors that contribute to conditions that disproportionately harm marginalized groups. This approach to knowledge also fails to grapple with the production of knowledge in that it does not see the discursive power reproduced through scientific discourses indecipherable by much of the public.[12]

Therefore, our notion of public access (PA) incorporates Freire's (1992) “dialogical cultural action." This first requires cooperation between freely acting subjects. Co-subjects openly communicate in materially and historically specific moments to transform oppressive knowledge systems. Relatedly is the importance for unity between establishment knowledge producers and those historically marginalized from the scientific process. This unity of action and theory calls for engendering the particularities of the historical and existential moment, which right now requires bridging digital and physical space. Actions necessitate organization between teachers and learners in an ongoing effort to transform how knowledge is produced. Specifically, organizational forms that help transfer power to those denied an authoritative voice, may equalize power relations in the knowledge production process. In short, solidarity among those with varying forms of knowledge can help create the conditions for freely acting individuals to transform social reality.

Dialogical cultural action recognizes that education and the dissemination of knowledge take place at a cultural level. However, such action at the cultural level has material consequences when it evolves through the mutually constitutive process of learners and teachers engaging in a process committed to collective education. This form of liberating education, would involve social scientists on one hand identifying with the knowledge of marginalized groups and on the other hand working to dispel uncritical or unjust elements of such knowledge. The conducting of research which explicitly supports the goals of the state, military, and industrial complexes sustains hegemonic discourses and structures rather than challenging unjust forms of knowledge and has no place in a sociology, or other scientific project oriented around our conception of PA.

PA looks very different than OA in terms of the way it is framed and the way it operates. Following Habermas (1984) and his emphasis on creating democratic communication space, PA rests on the combination of co-produced knowledge with open dissemination processes, and an academic environment that values teaching, learning, and sharing. Similarly, Mills (1959) argues that for social sciences to be useful outside of university walls, "the end product of any liberating education is simply the self-educating, self-cultivated man and woman; in short, the free and rational individual" (187). The notion of reason and knowledge are contested social and political spaces. While we agree with the commitment to developing "self-cultivating publics" (Mills 1959: 186), not everyone deems university education as necessary, nor sufficient for creating a society based on reason, freedom, and justice. Therefore, maintaining a high level of reflexivity as it pertains to the social, political, and economic location the social scientist occupies may provide the foundation needed to co-develop knowledge.

Also of critical importance is debunking myths to be found in social science research. At core, PA is more about means: knowledge production. OA is about ends: knowledge dissemination. PA could look similar to OA when a challenge to established frames of knowledge takes place. PA would provide an alternative medium for intellectuals to engage publics without interference from mainstream radio and television, and economic and political elites. By using the far-reaching power of the Internet, more people would have access to alternative forms of knowledge. When such mediums are insufficient, place based engagement with publics is necessary. Moreover, tension still exists when institutional forms of knowledge via the state influence the institution of science; scientists can still be co-opted. In short, PA may better serve society if it rests on a foundation where social scientists work with publics instead of creating knowledge for publics. This may not only lead to more just knowledge, but also help us garner a better understanding of our social worlds. 


\section{What Does (Might) Public Access Look Like?}

Some of the following examples and suggestions point to what public access looks like as a praxis committed to expanding a democratic cybershpere. Committed to a structural evaluation of racial and ethnic inequality and to working toward just solutions, the Applied Research Center (ARC) stands as a model for how empirically robust research can be driven by community concerns, and disseminated in ways that impact public policy and raise social consciousness. Schooled in journalism, social sciences, media studies, computational sciences, policy making, and grassroots activism, ARC staff and board represent a wide ranging set of skills collectively directed to actualizing a racially just world. In a recent victory, ARC developed a web-based public education campaign aimed at stopping the use of the word "illegal" to refer to immigrants. The Associated Press dropped its use of this word at a critical moment in national debates over immigration reform, prioritizing language that reflects instead of ignores all people's human dignity. Similarly, they conduct research with and for low-income communities and communities of color. In a recent report, The Color of Food, they not only weigh in on scholarly debates regarding structural racism in the food system by revealing racial inequality throughout the food supply chain, but work with community groups, schools, and activist organizations to develop solutions to these problems (Liu and Apollon 2011).

A web-based example is the public media archive and fair use advocacy network, Critical Commons, originally funded by John D. and Catherine T. MacArthur Foundation, with ongoing support from USC Institute for Multimedia Literacy. In short, this platform provides a digital space for users to create, debate, and rework captured, ripped and stored media under the fair use statute. As Anderson and McPherson (2011) put it,

Digital scholarship often renders unstable the divisions between scholarship and pedagogy...Critical Commons recognized no sharp distinction between these two realms...(and) was designed to support in-class teaching, student participation, and self-guided study as well as research and publication" (144).

There is great potential for such platforms to rupture banking models of education. While current academic reward systems might have difficulty adjusting to participatory forms of learning and knowledge production, scholars themselves can further models that open the process of production using tools that engage an open intellectual commons.

As we have argued elsewhere in the context of contemporary social movements, the bringing together of platforms, portals, and places, is one way to build collective power through democratic means that elevate engagement between myriad publics (Sbicca and Perdue 2013). Platforms represent the tactics and/or ideologies that inform alternatives. For example, anti-oppression trainings both in academic and public spaces can be used to further efforts aimed at understanding and dismantling various interlocking systems that reproduce inequalities. Or as was discussed above, Critical Commons is a digital platform that alters user/creator/participant relations. Smaller affinity groups can form to address specific concerns that then report back to a larger group in a democratic communication process. Portals are central to our notion of PA. These are digital communication tools. Social media plays a particularly important role in bridging scholars, activists, and front line communities. These portals are not in and of themselves liberatory (e.g. using Twitter as a means to simply increase scholarly buzz and citations), but can be used to bring many different groups together in digital and physical space. We conclude, then, with places. The creation of a democratic cybersphere is only possible to the degree to which publics gain more power in the material world. Harkening back to Hardt and Negri (2009), the platforms and portals mentioned above should be aimed at taking back control of the cultural commons, knowledge being itself a product of collective labor and a key element to future social reproduction. Digital technologies and tools are a product of physical and social systems, which in turn change the use and form of the digital. How praxis looks in this context is of the utmost importance.

\section{Conclusion}

In this article we presented the uneven and contradictory nature of current efforts to change how scientific knowledge is communicated and shared both within and outside the academic community. Moreover, we investigated the structural influences dissuading academics from pursuing either open access or public access. This is particularly troubling within sociology, which is the discipline of society and failing to engage in a reciprocal partnership for emancipatory social change via participatory scholarship is a missed opportunity. 
We recognize OA is not a panacea, but contend that it is a necessary component of what we call PA, or a stride towards socially relevant knowledge production. Research conducted with the public allows for better understandings of our social world and the development of feasible solutions to pressing social problems. In addition, research conducted with the knowledge that findings will be shared with chosen communities will likely lead to works more meaningful for us all. Scholars privileged pedagogical dais offers an opportunity to help raise awareness of injustices. Critical scholars have long used research to help the causes of various social movements and this approach, coupled with a political imagination, may facilitate meaningful change. Despite the very real institutional roadblocks and perverse incentives of academic institutions, a PA approach can help scholars produce socially relevant knowledge.

To summarize, operating from the standpoint of PA would link means and ends together: the democratization of access to knowledge and the co-construction of knowledge between publics and intellectuals. In this model, institutions that perpetuate educational inequality are challenged. While the goal of OA is to make scholarly research free, PA focuses on the structural problems that prevent this from happening. The tools of education such as computers, good teachers, books, libraries, science labs, and access to college or trade schools are as important as finding ways to spread knowledge. This conception of PA rests on the premise that institutions of knowledge are enriched by a commitment to reflecting the standpoint of historically marginalized groups, that socially relevant research can be produced through more participatory methods, and that structural inequalities are worth challenging both inside and outside academia.

\section{Appendix A. OA Status of Top 50 Sociology Journals Ranked by Impact Factor}

\begin{tabular}{|c|c|c|c|c|c|c|}
\hline Rankings & Journal Title & Impact Factor & $\begin{array}{l}\text { 5-year Impact } \\
\text { Factor }\end{array}$ & $\mathbf{O A}$ & Publisher & Cost per Article \\
\hline 1 & $\begin{array}{c}\text { Annual Review of } \\
\text { Sociology }\end{array}$ & 3.702 & 5.953 & No & $\begin{array}{c}\text { Annual Reviews: } \\
\text { A Non-Profit } \\
\text { Publisher }\end{array}$ & $\$ 20$ \\
\hline 2 & $\begin{array}{c}\text { American Journal of } \\
\text { Sociology }\end{array}$ & 3.476 & 5.411 & No & $\begin{array}{l}\text { University of } \\
\text { Chicago Press }\end{array}$ & $\$ 10 / \$ 14$ \\
\hline 3 & $\begin{array}{c}\text { American } \\
\text { Sociological Review }\end{array}$ & 3.221 & 5.578 & No & $\begin{array}{l}\text { American } \\
\text { Sociological } \\
\text { Association/ } \\
\text { Sage }\end{array}$ & $\$ 14 / \$ 32$ \\
\hline 4 & Social Networks & 2.349 & 3.328 & No & Elsevier & $\$ 31.50$ \\
\hline 5 & $\begin{array}{c}\text { Sociology of Health } \\
\text { \& Illness }\end{array}$ & 2.041 & 2.598 & Yes & Wiley-Blackwell & - \\
\hline 6 & $\begin{array}{l}\text { Sociological } \\
\text { Methods \& } \\
\text { Research }\end{array}$ & 1.850 & 3.596 & No & Sage & $\$ 25$ \\
\hline 7 & Sociological Theory & 1.710 & 2.031 & No & Wiley-Blackwell & Vary by title \\
\hline 8 & $\begin{array}{l}\text { British Journal of } \\
\text { Sociology }\end{array}$ & 1.702 & 2.457 & No & Wiley-Blackwell & Vary by title \\
\hline 9 & Social Problems & 1.698 & 2.586 & No & $\begin{array}{c}\text { University of } \\
\text { California Press }\end{array}$ & $\$ 12 / \$ 14$ \\
\hline 10 & $\begin{array}{c}\text { Population and } \\
\text { Development } \\
\text { Review }\end{array}$ & 1.588 & 2.230 & No & Wiley-Blackwell & Vary by title \\
\hline 11 & $\begin{array}{c}\text { Annual Review } \\
\text { of Law and Social } \\
\text { Science }\end{array}$ & 1.583 & 1.648 & No & $\begin{array}{c}\text { Annual Reviews: } \\
\text { A Non-Profit } \\
\text { Publisher }\end{array}$ & $\$ 20$ \\
\hline
\end{tabular}




\begin{tabular}{|c|c|c|c|c|c|c|}
\hline 12 & $\begin{array}{c}\text { Journal of Marriage } \\
\text { and Family }\end{array}$ & 1.553 & 2.957 & No & Wiley-Blackwell & Vary by title \\
\hline 13 & $\begin{array}{l}\text { Economy and } \\
\text { Society }\end{array}$ & 1.527 & 2.553 & No & Routledge & $\$ 30$ \\
\hline 14 & $\begin{array}{c}\text { Law \& Society } \\
\text { Review }\end{array}$ & 1.490 & 1.727 & No & Wiley-Blackwell & Vary by title \\
\hline 15 & Politics \& Society & 1.487 & 1.436 & No & Sage & $\$ 25$ \\
\hline 16 & $\begin{array}{c}\text { Health Sociology } \\
\text { Review }\end{array}$ & 1.486 & - & No & $\begin{array}{c}\text { eContent Man- } \\
\text { agement }\end{array}$ & $\$ 35$ \\
\hline 17 & $\begin{array}{l}\text { Kolner Zeitschrift } \\
\text { Fur Soziologie Und } \\
\text { Sozialpsychologie }\end{array}$ & 1.457 & 1.308 & No & $\begin{array}{l}\text { VS Verlag für } \\
\text { Sozialwissen- } \\
\text { schaften }\end{array}$ & $\$ 34$ \\
\hline 18 & Sociology & 1.455 & 1.969 & No & Sage & $\$ 25$ \\
\hline 19 & Sociologia Ruralis & 1.442 & 2.010 & No & Wiley-Blackwell & Vary by title \\
\hline 20 & $\begin{array}{l}\text { Sociology of } \\
\text { Education }\end{array}$ & 1.438 & 2.818 & No & Sage & $\$ 14 / \$ 32$ \\
\hline 21 & Human Ecology & 1.402 & 1.712 & No & Springer & $\$ 34$ \\
\hline 22 & Global Networks & 1.380 & 2.018 & No & Wiley-Blackwell & Vary by title \\
\hline 23 & Social Forces & 1.379 & 2.492 & No & $\begin{array}{c}\text { University of } \\
\text { North Carolina } \\
\text { Press }\end{array}$ & $\$ 5$ \\
\hline 24 & $\begin{array}{c}\text { Work, Employment } \\
\text { \& Society }\end{array}$ & 1.348 & 1.977 & No & Sage & $\$ 25$ \\
\hline 25 & Language in Society & 1.341 & 1.500 & No & $\begin{array}{c}\text { Cambridge } \\
\text { University Press }\end{array}$ & $\$ 30 / \$ 34$ \\
\hline 26 & Gender \& Society & 1.339 & 2.405 & No & Sage & $\$ 19 / \$ 25$ \\
\hline 27 & $\begin{array}{l}\text { Work and } \\
\text { Occupations }\end{array}$ & 1.323 & 2.129 & No & Sage & $\$ 25$ \\
\hline 28 & Theory and Society & 1.304 & 1.583 & No & Springer & $\$ 34$ \\
\hline 29 & Discourse $\&$ Society & 1.300 & 1.623 & No & Sage & $\$ 25$ \\
\hline 30 & $\begin{array}{l}\text { Social Science } \\
\text { Research }\end{array}$ & 1.278 & 1.927 & No & Elsevier & $\$ 31.50$ \\
\hline 31 & Acta Sociologica & 1.268 & 1.451 & No & Sage & $\$ 25$ \\
\hline 32 & $\begin{array}{c}\text { Ethnic and Racial } \\
\text { Studies }\end{array}$ & 1.245 & 1.900 & No & Routledge & $\$ 30$ \\
\hline 33 & Poetics & 1.227 & 1.602 & No & Elsevier & $\$ 39.95$ \\
\hline 34 & $\begin{array}{c}\text { European } \\
\text { Sociological Review }\end{array}$ & 1.210 & 1.607 & No & $\begin{array}{c}\text { Oxford } \\
\text { University Press }\end{array}$ & $\$ 25$ \\
\hline 35 & $\begin{array}{l}\text { Annals of Tourism } \\
\text { Research }\end{array}$ & 1.165 & 2.204 & No & Elsevier & $\$ 31.50$ \\
\hline 36 & $\begin{array}{l}\text { Zeitschrift Fur } \\
\text { Soziologie }\end{array}$ & 1.140 & 0.952 & Yes & - & - \\
\hline 37 & $\begin{array}{l}\text { Agriculture and } \\
\text { Human Values }\end{array}$ & 1.123 & 1.288 & No & Springer & $\$ 34$ \\
\hline 38 & $\begin{array}{c}\text { Journal of Sports \& } \\
\text { Social Issues }\end{array}$ & 1.075 & 1.307 & No & Sage & $\$ 25$ \\
\hline 39 & Leisure Sciences & 1.036 & 1.468 & No & Routledge & $\$ 30$ \\
\hline 40 & $\begin{array}{l}\text { The Sociological } \\
\text { Review }\end{array}$ & 1.019 & 1.448 & No & Wiley-Blackwell & Vary by title \\
\hline 41 & $\begin{array}{c}\text { Society \& Natural } \\
\text { Resources }\end{array}$ & 1.016 & 1.626 & No & Routledge & $\$ 37$ \\
\hline
\end{tabular}




\begin{tabular}{|c|c|c|c|c|c|c|}
\hline 42 & City \& Community & 1.000 & - & No & Wiley-Blackwell & Vary by title \\
\hline 43 & $\begin{array}{l}\text { Rationality and } \\
\text { Society }\end{array}$ & 1.000 & 1.038 & No & Sage & $\$ 25$ \\
\hline 44 & $\begin{array}{l}\text { Sociological } \\
\text { Methodology }\end{array}$ & 1.000 & 2.203 & No & Wiley-Blackwell & Vary by title \\
\hline 45 & Youth \& Society & 1.000 & 2.038 & No & Sage & $\$ 25$ \\
\hline 46 & Cultural Sociology & 0.971 & 0.971 & No & Sage & $\$ 25$ \\
\hline 47 & $\begin{array}{c}\text { Journal for the } \\
\text { Scientific Study of } \\
\text { Religion }\end{array}$ & 0.929 & 1.532 & No & Wiley-Blackwell & Vary by title \\
\hline 48 & $\begin{array}{c}\text { International } \\
\text { Sociology }\end{array}$ & 0.920 & 1.107 & No & Sage & $\$ 25$ \\
\hline 49 & Mobilization & 0.911 & - & No & $\begin{array}{c}\text { San Diego State } \\
\text { University }\end{array}$ & $\$ 49 /$ year \\
\hline 50 & $\begin{array}{l}\text { International } \\
\text { Journal of } \\
\text { Intercultural } \\
\text { Relations }\end{array}$ & 0.897 & 1.526 & No & Elsevier & $\$ 31.50$ \\
\hline
\end{tabular}

\section{Endnotes}

1. Although we are sociologists, and position this article within some key sociological debates, the issues raised transcend these disciplinary walls. Natural and social sciences and the humanities regularly debate the degree of public transparency and permeability acceptable by their discipline or science writ large. Some examples include critical praxis, participatory action research, "public geography", "public criminology", Science Gallery in Dublin brings art-science collaborations into public debate, and the Center for Public Engagement with Science and Technology.

2. We recognize that the digital humanities have been much more forward thinking than any other sector of academia. Our intent is for our examples to reveal some of the ways that scholars across the spectrum are thinking about access, reward structures, and knowledge production.

3. Take for instance our examination of the accessibility of sociology journals, only a few of which allow their content to be freely accessible to those outside of the university (see Appendix A).

4. Our definition of "public" links traditionally Marxist notions of the proletariat (i.e. low-income and working classes under regimes of wage labor and private property) with critical understandings of race, gender, sexuality, nationality, religion, age, and ability (i.e. people experiencing intersecting social systems of oppression). Thus, there is quite a bit of variability within the publics we are most interested in engaging. This in turn has implications for both place based and internet based participation and collaboration.
5. From 1986-2005 the cost of academic journals for research libraries increased $302 \%$ while the number of academic journals grew by $1.9 \%$ per year (Association of Research Libraries 2006). In 2007 the average price for subscribing to academic journals in chemistry was $\$ 3,429, \$ 2,071$ in engineering, $\$ 820$ in business, and only $\$ 528$ in sociology (Lee et al. 2007)

6. The cost of self-archiving is usually between $\$ 1500$ and $\$ 3000$.

7. Across a number of natural and social sciences and humanities, research by Harley et al. (2010) investigates faculty values on research and publishing, specifically around tenure and promotion, ways of disseminating research, access to resources for research, level of collaboration, and engagement with the public. Social sciences regularly undervalue $\mathrm{OA}$, but engage the public to the degree it is professionally useful.

8. Given the purported fiscal constraints at many public universities, OA may begin leading to more citations once libraries have to cancel their subscriptions to cut costs.

9. All of the successful university OA resolutions/ mandates have allowed 'opt out' exceptions for pretenure folks who don't have the 'clout' to negotiate for OA with powerful publishers.

10. We recognize that there are also peer-reviewed $\mathrm{OA}$ journals that are perceived as less intellectually legitimate.

11. Posts dealing with contemporary social problems 
such as gender or racial inequality will get picked up by more widely read blogs or social media platforms, resulting in greater social dialogue and mobilization aimed at alleviating such inequalities

12. Smith (2008) argues that in the field of sociology there is not simply a problem with lexical practices, but that sociology tends to ignore people at the ground level; we suffer from the " 14 th floor effect" whereby our language places us above people and not with people. If sociologists are not infusing their writing with the standpoints of those being written about, there is the risk that the agency of those in the text becomes obscured; the text as mediator between writer and reader organizes power relations along the lines of expert and non-expert, further obfuscating the writer's subjectivity.

\section{References}

Agger, Ben, 2000. Public Sociology: From Social Facts to Literary Acts. Lanham, MD: Rowman \& Littlefield Publishers.

Agger, Ben. 2004. The Virtual Self: A Contemporary Sociology. Malden, MA: Blackwell Publishing.

Agger, Ben. 2006. Critical Social Theories: An Introduction. Second Edition. Boulder: Paradigm Publishers

Altieri, Miguel, 2010. “Berkeley-BP Deal Only Looks Worse PostSpill.” The Daily Californian. July 26, 2010.

Anderson, Steve, and Tara McPherson. 2011. "Engaging digital scholarship: Thoughts on evaluating multimedia scholarship." Profession. 2011(1): 136-151.

Aronowitz, Stanley, 2000. The Knowledge Factory: Dismantling the Corporate University and Creating True Higher Learning. Boston, MA: Beacon.

Association of Research Libraries. 2006. ARL Statistics: 20042005. 10. Washington D.C.: Association of Research Libraries.

Berlin Declaration on OA to Knowledge in the Sciences and Humanities, 2003 (http://oa.mpg.de/lang/en-uk/berlinprozess/berliner-erklarung) Accessed March 15, 2010

Bourdieu, Pierre, 1989. “The Corporatism of the Universal." Telos. 81:99-110.

Bourdieu, Pierre and Loïc Wacquant, 1993. “From Ruling Class to Field of Power: An Interview with Pierre Bourdieu on La noblesse d'état." Theory, Culture and Society. 10:19-44.

Bourdieu, Pierre, 1996. "Intellectuals and the Internalization of Ideas: An Interview with M'Hammed Sabour.” International Journal of Contemporary Sociology. 33:237-253.

Boyer, Ernest L. 1996. “The Scholarship of Engagement.” Journal of Public Service and Outreach. 1(1):11-20.

Burawoy, Michael, 2008. "An Open Letter to C. Wright Mills." Antipode. 40:365-375.

Burawoy, Michael, 2005. 2004 Presidential Address: For Public Sociology." American Sociological Review. 70(1): 4-28.
Castells, Manuel, 2000. The Rise of the Network Society. Oxford, UK: Blackwell Publishers.

Castells, Manuel, 2009. Communication Power. Oxford, UK: Oxford University Press.

Collins, Patricia Hill, 2007. "Going Public: Doing the Sociology That Had No Name”. Pp. 101-116 in Public Sociology: Ideas, Arguments and Visions for the Future, edited by Dan Clawson, Robert Zussman, Joya Misra, Naomi Gerstel, Randal Stokes, Douglas L. Anderton, and Michael Burawoy. Berkeley, CA: University of California Press.

Davis, Philip M. 2011. "Open access, readership, citations: a randomized controlled trial of scientific journal publishing." The FASEB Journal. Published online March 30. (http:// www.fasebj.org/content/early/2011/03/29/fj.11-183988. abstract).

Ember, Lois R. 2002. "Science in the Service of Security: Science \& Technology Directorate in the Department of Homeland Security is charged with developing technologies to thwart terrorism." Chemical and Engineering News. 80(49): 25-28, 38 .

Emery, Kim. 2010. ““Crisis Management” in Higher Education: RCM and the Politics of Crisis at the University of Florida." Cultural Logic.

Espeland, Wendy, 1998. The Struggle for Water: Politics, Rationality, and Identity in the American Southwest. Chicago, IL: University of Chicago Press.

Eysenbach, Gunther. 2011. "Can tweets predict citations? Metrics of social impact based on Twitter and correlation with traditional metrics of scientific impact." Journal of Medical Internet Research. 13(4).

Fanon, Franz. 1967. Black Skin, White Masks. New York: Grove Press.

Feagin, Joe and Hernán Vera, 2008. Liberation Sociology (2nd Edition). Boulder, CO: Paradigm Publishers.

Fitzpatrick, Kathleen. 2012. "Reading (and Writing) Online, Rather Than on the Decline." Profession 2012(1): 41-52. 
Freire, Paulo, 1992. Pedagogy of the Oppressed. New York, NY: The Continuum Publishing Company.

Gattone, Charles F, 2006. The Social Scientist as Public Intellectual: Critical Reflections in a Changing World. Oxford, UK: Rowman and Littlefield Publishers.

Giroux, Henry A. 2002. "Neoliberalism, corporate culture, and the promise of higher education: The university as a democratic public sphere." Harvard Educational Review. 72(4): 425-464.

Giroux, Henry and Susan Searls Giroux. 2006. Take Back Higher Education: Race, Youth, and the Crisis of Democracy in the Post-Civil Rights Era. New York, NY: Palgrave Macmillian.

Habermas, Jurgen. 1984. The Theory of Communicative Action. Boston, MA: Beacon Press.

Hardt, Michael, and Antonio Negri. 2009. Commonwealth. Cambridge, MA: The Belknap Press of Harvard University Press.

Harley, Diane and Sophia Krzys Acord. 2011. Peer Review in Academic Promotion and Publishing: Its Meaning, Locus, and Future. UC Berkeley: Center for Studies in Higher Education. (http://escholarship.org/uc/item/1xv148c8).

Harley, Diane, Acord, Sophia Krzys, Earl-Novell, Sarah, Lawrence, Shannon, \& King, C. Judson. 2010. Assessing the Future Landscape of Scholarly Communication: An Exploration of Faculty Values and Needs in Seven Disciplines. UC Berkeley: Center for Studies in Higher Education. (http://escholarship. org/uc/cshe_fsc).

Harnad, S., Brody, T., Vallieres, F., Carr, L., Hitchcock, S., Gingras, Y., Oppenheim, C., Hajjem, C. and Hilf, E. 2008. "The Access/ Impact Problem and the Green and Gold Roads to Open Access: An Update." Serials review 34: 1: 36-40.

Hess, Charlotte, and Elinor Ostrom. 2005. A Framework for Analyzing the Knowledge Commons: a chapter from Understanding Knowledge as a Commons: from Theory to Practice. Cambridge, MA: MIT Press.

Hoorn, Esther and Maurits van der Graaf. 2006. "Copyright Issues in Open Access Research Journals: The Authors' Perspective." D-Lib Magazine. 12: 2.

Horkheimer, Max and Adorno, Theodor. [1947] 2002. Dialectic of Enlightenment. Stanford: Stanford University Press.

Horowitz, Irving Louis, ed. 1967. The Rise and Fall of Project Camelot: Studies in the Relationship Between Social Science and Practical Politics. Cambridge, MA: M.I.T. Press.

ISI Web of Knowledge, 2010. "Journal Citation Reports." (http:// admin-apps.isiknowledge.com/JCR/help/h_impfact.htm). Accessed July 25, 2010.

Kuhn, Thomas. 2012. The Structure of Scientific Revolutions (50th Anniversary Edition). Chicago, IL: University of Chicago Press.

Lee C. Van Orsdel and Kathleen Born. 2007. "Periodical Price Survey 2007: Serial Wars.” Library Journal 132: 7: 43-48.
Lexchin, Joel, Lisa A. Bero, Benjamin Djulbegovic, Otavio Clark. 2003. "Pharmaceutical industry sponsorship and research outcome and quality: systematic review." The British Medical Journal 326:1167-1170.

Liu, Yvonne Yen, and Dominique Apollon. 2011. The Color of Food. New York, NY: Applied Research Center.

Marcuse, Herbert. 1964. One Dimensional Man: Studies in the Ideology of Advanced Industrial Society. Boston: Beacon Press.

Marx, Karl. 1998. The German Ideology. Amherst, NY: Prometheus Books.

Massey, Douglas S., 2007. “The Strength of Weak Politics.” Pp. 145-157 in Public Sociology: Ideas, Arguments and Visions for the Future, edited by Dan Clawson, Robert Zussman, Joya Misra, Naomi Gerstel, Randal Stokes, Douglas L. Anderton, and Michael Burawoy. Berkeley, CA: University of California Press.

Merger Mania, 2003. Scholarly Communication Reports. 7:2

Morgan Stanley. 2002. "Media Industry Overview: Scientific Publishing: Knowledge is Power," Equity Research Report Europe. September 30, 2002.

Mills, C. Wright, 1959. The Sociological Imagination. New York, NY: Oxford University Press.

Piven, Frances Fox, 2007. "From Public Sociology to Politicized Sociologist." Pp. 158-168 in Public Sociology: Ideas, Arguments and Visions for the Future, edited by Dan Clawson, Robert Zussman, Joya Misra, Naomi Gerstel, Randal Stokes, Douglas L. Anderton, and Michael Burawoy. Berkeley, CA: University of California Press.

Price, David, 2010. "Human Terrain Systems Dissenter Resigns, Tells Inside Story of Training's Heart of Darkness." Counterpunch. (http://www.counterpunch.org/ price02152010.html) Accessed March 15, 2010.

Sbicca, Joshua and Robert Todd Perdue. 2013. "Protest through Presence: Spatial Citizenship and Identity Formation in Contestations of Neoliberal Crises." Social Movement Studies. Online first. DOI: 10.1080/14742837.2013.822782.

Schiltz, Michael, Gert Verschraegen, Stefano Magnolo, 2005. "OA to Knowledge in World Society." Soziale Systeme. $11: 346-369$.

Scheff, Thomas J., 1995. "Academic gangs.” Crime, Law and Social Change. 23: 157-162.

Slaughter, Sheila and Gary Rhoades. 2004.Academic capitalism and the new economy: Markets, state and higher education. Baltimore, MD: Johns Hopkins University Press.

Smith, Dorothy, 1989. "Sociological Theory: Methods of Writing Patriarchy." Pp. 34-64 in Feminism and Sociological Theory, edited by Ruth A. Wallace. Newberry Park, CA: Sage Publications. 
Smith, Dorothy, 2008. "From the 14th Floor to the Sidewalk: Writing Sociology at the Ground Level." Sociological Inquiry. 78:417-422.

Smith-Lovin, Lynn, 2007. "Do We Need a Public Sociology? It Depends on What You Mean by Sociology." Pp. 124-134 in Public Sociology: Ideas, Arguments and Visions for the Future, edited by Dan Clawson, Robert Zussman, Joya Misra, Naomi Gerstel, Randal Stokes, Douglas L. Anderton, and Michael Burawoy. Berkeley, CA: University of California Press.

Stinchcombe, Arthur L., 2007. "Speaking Truth to the Public, and Indirectly to Power." Pp. 135-144 in Public Sociology: Ideas, Arguments and Visions for the Future, edited by Dan Clawson, Robert Zussman, Joya Misra, Naomi Gerstel, Randal Stokes, Douglas L. Anderton, and Michael Burawoy. Berkeley, CA: University of California Press.

Suber, Peter, 2003. "Removing the Barriers to Research: An Introduction to OA for Librarians." College \& Research Libraries News. 64:92-94, 113.

Suber, Peter, 2008. "Gratis an libre OA.” SPARC OA Newsletter. Issue \#124. (http://www.arl.org/sparc/publications/articles/ gratisandlibre.shtml.) Accessed March 18, 2010.

Swan, Alma, 2010. "The OA citation advantage: Studies and results to date.” (http://eprints.ecs.soton.ac.uk/18516/2/ Citation_advantage_paper.pdf.) Accessed March 19th, 2010.

Thomes, Katherine and Karen Clay. 1998. "University Libraries in Transition." ASEE Prism. April: 28.

Touraine, Alain, 2007. "Public Sociology and the End of Society." Pp. 67-78 in Public Sociology: Ideas, Arguments and Visions for the Future, edited by Dan Clawson, Robert Zussman, Joya Misra, Naomi Gerstel, Randal Stokes, Douglas L. Anderton, and Michael Burawoy. Berkeley, CA: University of California Press.
Tuchman, Gaye. 2009. Wannabe U: Inside the Corporate University. Chicago: University of Chicago Press.

Urry, John, 2005. "The Complexity Turn." Theory, Culture \& Society. 22:1-14.

Valsiner, Jaan, 2006. “OA” and its Social Context: New Colonialism in the Making?" Forum: Qualitative Sozialforschung. $7: 23$.

Van Dalen, Hendrik P. and Kene Henkens. 2012. Intended and Unintended Consequences of a Publish-or-Perish Culture." Journal of the American Society for Information Science and Technology. 63: 7: 1282-1293.

Wade, Lisa and Gwen Sharp. 2013. "Sociological Images: Blogging as Public Sociology." Social Science Computer Review. 31(2): 221-228.

Wallerstein, Immanuel, 2007. "The Sociologist and the Public Sphere." Pp. 169-175 in Public Sociology: Ideas, Arguments and Visions for the Future, edited by Dan Clawson, Robert Zussman, Joya Misra, Naomi Gerstel, Randal Stokes, Douglas L. Anderton, and Michael Burawoy. Berkeley, CA: University of California Press.

Wazana, Ashley. 2000. "Physicians and the Pharmaceutical Industry: Is a Gift Ever Just a Gift?" The Journal of the American Medical Association. 283: 3: 373-380.

Willinsky, John, 2006. The Access Principle: The Case for OA to Research and Scholarship. Cambridge, MA: MIT Press.

Wright, Erik Olin. 2010. Envisioning Real Utopias. New York, NY: Verso. 